\title{
Hermilo Borba Filho e o expressionismo
}

\author{
Igor de Almeida Silva ${ }^{1}$
}

Resumo: Neste artigo, busca-se observar e discutir, nas três peças de Hermilo Borba Filho - Electra no circo, João sem terra e A barca de ouro -, temas e procedimentos provenientes da dramaturgia expressionista, a fim de averiguar a dimensão da veia expressionista do "Teatro do Nordeste" na obra do autor pernambucano.

Palavras-chave: Expressionismo. Dramaturgia. Teatro do Nordeste. Tragédia regionalista.

\begin{abstract}
In this article, we seek to observe and discuss, in Hermilo Borba Filho's three plays - Electra no circo, João sem terra and A barca de ouro -, themes and procedures from Expressionist dramaturgy, in order to investigate the dimension of the Expressionist vein of the "Teatro do Nordeste" in the work of the author from Pernambuco.
\end{abstract}

Keywords: Expressionism. Dramaturgy. “Teatro do Nordeste”. Regionalist tragedy.

Résumé: Dans cet article, nous cherchons à observer et à discuter, dans les trois pièces de Hermilo Borba Filho - Electra no circo, João sem terra et $A$ barca de ouro , thèmes et procédures de la dramaturgie expressionniste, afin de déterminer la dimension de la veine expressionniste du «Teatro do Nordeste» dans le travail de l'auteur de Pernambuco.

Mots-clés: Expressionnisme. Dramaturgie. «Teatro do Nordeste». Tragédie régionaliste.

No livro Fora de cena, no palco da modernidade, Luís Augusto Reis afirma que, seguindo uma tendência predominante dos dramaturgos da primeira metade do século XX, Hermilo Borba Filho, nos anos 1940, também se aventura no desafio de reinventar o trágico na modernidade.

\footnotetext{
${ }_{1}^{1}$ Professor do Departamento de Teoria da Arte e Expressão Artística da Universidade Federal de Pernambuco (UFPE). Doutor em Artes pelo Programa de Pós-Graduação em Artes Cênicas da Universidade de São Paulo (2014), com período sanduíche na Université de la Sorbonne Nouvelle - Paris 3.
}

Este artigo está licenciado sob forma de uma licença Creative Commons Atribuição 4.0 Internacional,

que permite uso irrestrito, distribuição e reprodução em qualquer meio, desde que a publicação

original seja corretamente citada. https://creativecommons.org/licenses/by/4.0/deed.pt BR 
Ou seja, por meio de suas peças Electra no circo, João sem terra, A barca de ouro, e também $O$ vento do mundo, "Hermilo acreditou na possibilidade de uma tragédia moderna" (REIS, 2009, p. 347).

Um dos aspectos peculiares deste projeto dramatúrgico é que sua procura pela expressão universal do trágico toma como ponto de partida a "cor local" da região. Seu intento aproxima-se do ideário do movimento "Regionalista, Tradicionalista e, a seu modo, Modernista", de Gilberto Freyre, no qual a cultura local incide não apenas tematicamente, mas também nas características formais da obra.

Assim como a geração de críticos e historiadores, diretores e dramaturgos que protagonizam o estabelecimento do teatro moderno no Sudeste do Brasil, a atuação de Hermilo Borba Filho e de seus contemporâneos em Pernambuco (e, de modo mais amplo, na região Nordeste) também tem um caráter civilizatório, no sentido de instruir e de instaurar uma cultura teatral em sintonia com o teatro de seu tempo, realizado na Europa e nos Estados Unidos. O diferencial da cor local, o traço regionalista dessa dramaturgia, não dilui, entretanto, a força da influência estrangeira. Tanto Sábato Magaldi quanto Luís Augusto Reis reconhecem as raízes dramatúrgicas que dão sustentação ao projeto artístico de Hermilo. De suas quatro "tragédias regionalistas", pode-se identificar a influência de dois dramaturgos modernos de língua inglesa, T. S. Eliot e Eugene O’Neill: “Se O vento do mundo apresenta traços em comum com a dramaturgia de T. S. Eliot, Electra no circo, A barca de ouro e João sem terra ostentam uma influência ainda mais nítida do teatro de Eugenio O'Neill” (REIS, 2009, p. 356). E se, para Sábato Magaldi (2001), o valor artístico dessas peças é comprometido pela nitidez de suas raízes; para Luís Augusto Reis, 
[...] Hermilo não se limitou a parafrasear seus autores favoritos. Tomando-os como bússolas, o pernambucano tentou, com maior ou menor êxito, desenhar um caminho próprio no desafiador relevo da moderna dramaturgia ocidental; um caminho novo, original, nordestino, brasileiro (REIS, 2009, p. $351)$.

De certo modo, esse caminho de autoaprendizagem reflete-se em boa parte das peças produzidas pelos dramaturgos que fazem parte do assim chamado "Teatro do Nordeste" e que orbitam em torno da influência de Hermilo. A nitidez das raízes é perceptível em autores como Ariano Suassuna, Luiz Marinho, Aldomar Conrado, Aristóteles Soares, José Carlos Cavalcanti Borges, entre outros. Percebe-se a cultura teatral e literária de cada um deles e como ela os impulsiona à criação. Antes de tudo, para nós, são evidentes os leitores e espectadores de teatro que eles são. E, no caso de Hermilo, o quanto sua cultura teatral, no campo teórico, é vasta e significativa em seu trabalho artístico.

O processo civilizatório do teatro moderno em Pernambuco, em um primeiro momento, é muito mais interno do que externo. Trata-se de um gesto deflagrador em que se inaugura uma prática teatral moderna, e também brasileira, ao mesmo tempo em que se procura aprender de maneira autodidata os fundamentos que regem este ofício. Aqui reside, em grande medida, a principal contribuição de homens de teatro como Samuel Campêlo, Valdemar de Oliveira e Hermilo Borba Filho: não exatamente pelo valor de suas obras, mas pelo movimento que instauram e que mantêm tenazmente ao longo de suas vidas.

\section{"A veia expressionista"}


Já é de nosso conhecimento, por meio do estudo de Reis (2009) acerca do pensamento teatral de Hermilo, seu interesse pela poética expressionista no teatro. Em artigos e críticas em jornais e revistas de arte, publicados nos anos 1940, Hermilo demostra seu entusiasmo e conhecimento acerca dessa vertente estética da primeira metade do século XX, assim como de seus principais expoentes no teatro de língua alemã e de seus difusores fora dos limites geográficos da Europa. Entusiasmo que não se restringe aos campos da crítica e teoria teatral, mas que se expande para o da dramaturgia. Como afirma Reis (2009, p. 357), as peças de Hermilo "quase sempre pendem para o expressionismo, mesmo quando, na estrutura formal, parecem se aproximar de uma estética realista”.

A veia expressionista do "Teatro do Nordeste" e, particularmente, na obra de Hermilo, como aponta Reis, nos parece um viés interpretativo pertinente justamente porque ele evidencia de certa forma aspectos de uma trajetória de aprendizagem, e também suas influências dramatúrgicas mais próximas, como por exemplo, as obras de T. S. Elliot, Federico García Lorca e Eugene O’Neill. Este último é o modelo imediato na fatura de suas três tragédias regionalistas: Electra no circo (1944), João sem terra (1947) e A barca de ouro (1949), publicadas em 1952, pelas Edições Teatro do Estudante de Pernambuco, em volume único, sob o título geral Teatro.

Quando da montagem de Além do horizonte, de Eugene O'Neill, pelo Teatro Universitário de Pernambuco (TUP), em 1949, Hermilo diz o seguinte sobre o autor norte-americano:

Hoje à noite, o Teatro Universitário lançará em Pernambuco o maior dos dramaturgos modernos: Eugene O’Neill. Não se conhece, no teatro contemporâneo, nenhum dramaturgo tão 
essencialmente da arte dramática quanto O’Neill - toda a sua produção intelectual é de teatro - com exceção, apenas, de Ibsen, de quem sofreu influência, como de resto toda a geração de teatrólogos que veio após o gênio norueguês.

Tentando todos os estilos, O'Neill se firma como o mais potente e o mais realizador dos [...] dramaturgos modernos, enfileirando-se na história do teatro, ao lado de gênios como Sófocles, Ibsen, Strindberg, Claudel. Realizou com o mesmo vigor dramático obras realistas, expressionistas, históricas sob o ponto de vista pessoal da arte, bíblicas, dramas da terra, monólogos interiores, usando uma técnica própria e lançando mão da exteriorização do pensamento, do uso das máscaras, da elasticidade do tempo (BORBA FILHO, 1949, s/p).

O artigo extremamente elogioso e repleto de superlativos dá mostra da admiração de Hermilo pelo dramaturgo norte-americano. Os motivos são variados e podemos deduzir alguns: 1) exclusividade de sua produção artística no campo do teatro; 2) ecletismo de estilos, experimentando vários gêneros e tendências artísticas de vanguarda (como por exemplo, o expressionismo), tal qual o próprio Hermilo procura realizar em sua trajetória;3) qualidade de sua obra que, segundo a seleção de Hermilo, coloca-o no panteão da dramaturgia universal, clássica e moderna, no qual todos os autores são de origem europeia, com exceção de O’Neill. Como Hermilo diz no mesmo artigo, ao citar o livro Teatro contemporâneo, de Alfredo de la Guardía:

[...] Ibsen aparece como o marco do drama entre o período romântico e o realista-simbolista, Shaw como a estaca zero da comédia e O’Neill como o autor que mais criou verdadeiras obras para a cena. É fenômeno interessante que, justamente de uma nação moça, surja o dramaturgo mais sério de todo o mundo, desprezando o anedótico e voltando-se essencialmente para a luta íntima do homem. Todo o seu teatro reflete essa busca e esse eixo: o homem em luta consigo mesmo, diante do mundo (BORBA, FILHO,1949, s/p). 
Esse "fenômeno interessante", de o maior dramaturgo moderno ser de uma "nação moça", os Estados Unidos da América, sem tradição teatral, é certamente inspirador para Hermilo. Assim como Lorca, o teatro de O'Neill aproxima-se dos ideais artísticos do dramaturgo pernambucano e inspira seu projeto estético de um teatro moderno para o Nordeste brasileiro.

Outro aspecto peculiar desse artigo é que as características da obra de O’Neill que Hermilo observa são temas típicos da dramaturgia expressionista: o homem em luta consigo mesmo, diante do mundo. Segundo Catherine Mounier, a obra de O'Neill apresenta frequentemente o seguinte esquema: "Um herói central, pivô de um drama, muitas vezes à imagem do autor, assombrado pela morte, que se divide, procura a unidade de sua personalidade e parte em busca de valores espirituais após perder a fé" (MOUNIER, 1971, p. 337, tradução nossa). ${ }^{2}$

O’Neill é um dos responsáveis pela introdução da dramaturgia expressionista nos Estados Unidos. Isso se deve pela leitura atenta e aprofundada da obra de Strindberg e de autores alemães filiados ao expressionismo. Além disso, "No momento em que o teatro norteamericano focalizou a produção das vanguardas europeias em busca de novos parâmetros, a dramaturgia expressionista era de fato, o marco mais saliente do relevo" (LIMA, 2002, p. 215-216).

Como movimento, o expressionismo surge na primeira década do século XX em países de língua alemã, reunindo sob sua égide artistas e obras das mais variadas expressões: literatura, artes plásticas,

\footnotetext{
${ }^{2}$ No original : «Un héros central, pivot d'un drame, souvent à l'image de l'auteur, hanté par la mort, qui se dédouble, recherche l'unité de sa personalité et part à la quête de valeurs spirituelles après avoir perdu la foi».
} 
arquitetura, cinema, música, dança e teatro. Suas origens encontram-se na estética romântica cujo legado permite ao expressionismo resgatar procedimentos estéticos que se configuram como uma contrarresposta ao naturalismo. No campo do teatro, a originalidade do drama expressionista encontra-se no fato de ele "revigorar o individualismo romântico com a centralização da ação dramática na consciência e na percepção do protagonista, ao mesmo tempo em que dissolvia ou eliminava os componentes localistas do teatro romântico" (LIMA, 2002, p. 190). Segundo Mariângela Alves de Lima (2002, p. 190),

O impacto e a prolongada repercussão da dramaturgia expressionista nos países de língua alemã e, mais tarde, nas Américas resulta da alta definição de uma poética apoiada estruturalmente sobre elementos fixos reconhecíveis nas obras de diferentes autores e de uma continuidade temporal que vai da primeira década do século XX até a ascensão dos nazistas ao poder, em 1933.

Sua repercussão em outros países se dá principalmente no Leste europeu e na América. Na Europa mediterrânea, ele possui menor penetração em virtude da repercussão de movimentos como o dadaísmo, o surrealismo e o futurismo em seus países de origem.

Segundo Philippe Ivernel, o teatro ocupa posição estratégica no campo da literatura expressionista, pois é por meio dele que a experiência trágica é retomada: "O teatro expressionista não reaviva esse ou aquele motivo trágico, ele os acumula, pois pretende conjurar a essência da própria tragédia, por um processo de abstração que é semelhante à magia" (IVERNEL, 1971, p. 79, tradução nossa). ${ }^{3}$ Como uma

\footnotetext{
${ }^{3}$ No original : «Le théâtre expressioniste ne ressuscite pas tel ou tel motif tragique, il acumule les motifs tragiques, car il vise à conjurer l'essence de la tragédie même, par un processus d'abstraction qui s'apparente à la magie».
} 
linha contínua, a herança do trágico marca os momentos mais determinantes da literatura e do teatro de língua alemã, indo do Trauerspiel ao drama expressionista.

A vinculação entre a experiência trágica da Antiguidade e o expressionismo alemão dá novo sentido à veia expressionista do "Teatro do Nordeste", visto que os temas e os traços expressionistas da dramaturgia de Hermilo - especialmente nas três peças que compõem o livro Teatro, de 1952 - indicam uma dupla visada: "traduzir" na modernidade o espírito trágico grego, ambientado aos temas e aspectos culturais da região Nordeste, e propor uma linguagem cênica que escape do naturalismo, vertente à qual Hermilo renega e combate em seus artigos e críticas teatrais e que, na sua obra dramatúrgica, procura evitar. O’Neill parece ser o modelo mais adequado para a criação de uma tragédia regionalista e, a seu modo, expressionista.

\section{Norma e instinto}

Nas três tragédias regionalistas de Hermilo Borba Filho - Electra no circo, João sem terra e $A$ barca de ouro -, podemos encontrar certos temas e procedimentos expressionistas que, de antemão, destacam-nas do quadro de peças do dramaturgo. Talvez o mais evidente deles, já apontado inclusive por Reis em seu estudo, diz respeito ao conflito entre norma e instinto que, por sua vez, pressupõe também a oposição entre uma geração mais velha e outra mais jovem. Esse conflito básico da dramaturgia expressionista é inaugurado pela peça $O$ despertar da primavera, de Frank Wedekind, autor e obra que são precursores do movimento. 
De acordo com Mariângela Alves de Lima (2002, p. 193), essa peça "é uma hábil transição entre o Naturalismo (com a sua ênfase nos dados externos da experiência) e a utilização de símbolos na trama da escritura". A metáfora do título da peça diz respeito à primavera que desperta nos adolescentes, isto é, o despertar da sexualidade e da etapa reprodutiva que é uma condição instintiva natural dos seres vivos, porém contrariada pelas normas sociais: "Ansiosas e ignorantes, as crianças se debatem (e algumas acabam por ferir-se mortalmente) contra o áspero muro de negação encarnado pelos pais e pelos mestres". (LIMA, 2002, p. 193).

Todavia, esse conflito central que opõe gerações possui uma fonte ainda mais longínqua: trata-se da herança greco-latina do teatro na Antiguidade. Já é de conhecimento comum entre nós que o tema que permeia boa parte das tragédias gregas até a comédia nova romana diz respeito à disputa entre as gerações, isto é, ao embate entre pais e filhos. Em certa medida, esse antagonismo reforça os laços que vinculam o drama expressionista com a herança trágica da Antiguidade.

Em Electra no circo, retomando o mito grego da família dos Atridas, a fábula da peça e seus personagens são localizados em um circo. A cor local aqui é diluída em detrimento à aproximação do universo circense em que os personagens são identificados por suas funções artísticas: Electra torna-se A Moça do Arame; Orestes, O Rapaz do Trapézio; Agamêmnon, O Dono do Circo; Clitemnestra, A Equitadora; Egisto, O Domador; Pílades, O Homem Lagarto, etc. Diferentemente de Mourning becomes Electra, de Eugene O'Neill, e de Senhora dos afogados, de Nelson Rodrigues, Borba Filho divide a ação dramática da peça em torno dos filhos de O Dono do Circo/Agamêmnon: A Moça do Arame/ 
Electra e O Rapaz do Trapézio/ Orestes. Ambos são conduzidos pelo ímpeto da vingança; opõem-se à Equitadora/ Clitemnestra que os oprime ou repele, mas a presença/ausência do Dono do Circo não deixa de possuir igualmente uma potência opressora que os impele ao ódio e à violência. Suas aparições como um fantasma, lembrança do passado ou voz do inconsciente evidencia o caráter obsessivo e involuntário de uma vontade superiora e misteriosa que os conduz à vingança.

Na peça seguinte, João sem terra, encontramos de modo mais enfático a figura do Pai opressor, arquétipo do poder constituído, elemento essencial da poética expressionista. A fábula é ambientada em uma propriedade rural da Zona da Mata de Pernambuco, um engenho de cana de açúcar decadente em função da ascensão das usinas de açúcar, mas sobretudo em detrimento da irracionalidade de seu protagonista, João, que se recusa a cultivar a terra. Sua obsessão (de simbologia nitidamente sexual) é manter a terra virgem, livre da intervenção do homem. Nela, não se pode nem cultivar, nem enterrar os mortos. Uma imagem idealizada e congelada onde não há nem a vida, nem a morte. Para ele, seu cultivo trata-se de uma violação que deve ser (e é) repelido de modo violento. Como substituto, apenas o ventre feminino pode ser cultivado (ou violado). Para João, a mulher é tomada como objeto, propriedade do homem, de menor valor, enquanto que a terra é humanizada e, consequentemente, mais valorizada.

Aqui, o instinto surge como força destruidora que se sobrepõe à norma e ao progresso. O conflito de gerações pode ser observado por meio da relação entre João e seu filho Conrado. Fruto de um casamento sem amor com Beatriz, Conrado cresce desenvolvendo uma relação edipiana com a mãe, que vem a falecer no segundo ato, quando o filho se 
torna adulto. $\mathrm{O}$ antagonismo entre pai e filho tem como motivação a recusa do pai em cultivar e ceder suas terras para uma usina de açúcar, que pretende construir uma estrada de ferro que permitiria a circulação mais rápida de suas mercadorias. Além disso, o filho ressente-se pelo modo como o pai trata as mulheres da casa: sua mãe Beatriz, já morta, mas também Ana e Paula. A primeira, ex-amante de João, agora casada com Praxedes, antigo empregado da fazenda. A segunda, filha de Ana e João, por quem Conrado passa a nutrir também uma paixão incestuosa. Apenas os mais velhos sabem da paternidade de João.

Apesar de sua insensatez, João não deixa de exercer domínio sobre aqueles que o rodeiam: o instinto torna-se a norma, pois a atração incestuosa entre pais e filhos, irmãos entre si, e o desejo fora do casamento é o aspecto recorrente dessa tragédia rural. João viola indistintamente as mulheres: seja a esposa, seja a amante, sejam as moradoras da fazenda, seja a própria filha, como sugere a cena do rapto de Paula, quando Conrado consegue registrar as terras sob seu nome e as cede para a construção da estrada. João rapta a própria filha como se esta fosse o último pedaço de terra do qual é proprietário e onde ainda é possível "semear". Fora isso, os filhos, Conrado e Paula, apaixonam-se um pelo outro, além de não esconderem a forte ligação ou atração pelos pais; no caso, Conrado pela mãe Beatriz e Paula pelo pai João. Por fim, o desejo fora do casamento é o que une os dois casais: João e Beatriz, Praxedes e Ana.

Em A barca de ouro, a atmosfera marítima de uma ilha de pescadores sugere mais uma vez a relação indistinta entre a natureza e o homem em que um interfere sobre o outro. Como diz Luís Augusto Reis, 
[...] as motivações inconscientes, principalmente as de ordem sexual, vão permear toda a trama, incidindo dramaticamente nas relações afetivas, dentro e fora do núcleo familiar. A inescapabilidade do destino conduzido pelas pulsões primárias da psique humana é refletida, metaforicamente, no sobrenatural, na lenda, na superstição: uma belíssima mulher, viajando em uma barca de ouro, seduz os pescadores, conduzindo-os inexoravelmente à morte (REIS, 2009, p. 367).

O desejo e a morte caminham juntos nessa peça e, assim como João sem terra, o instinto torna-se a norma. Isso porque, nessa ilha, o destino da maioria dos pescadores é morrer no mar, atraídos pela barca de ouro, enquanto as mulheres permanecem solitárias, abandonadas pelos maridos, seja pelas ausências da vida marítima, seja pela viuvez. Aqui, impera uma ordem superior misteriosa que incide sobre os instintos e a morte. Os mais jovens desejam escapar desse destino. Anselmo, Dona e Corina almejam sair da ilha, mas a força repressora dos mais velhos os impede. O Pai antagoniza com o filho Anselmo em função de seu desejo por Dona, que também desperta a atração de Corina (irmã de Anselmo), em um lesbianismo inconfesso.

\section{Eros e Tânatos}

De modo mais ou menos explícito, todas as peças culminam com a derrota da geração mais nova e a vitória dos pais. Estes se sobrepõem aos primeiros, mesmo na morte. Nos dramas expressionistas, a morte ou o suicídio é um destino comum do herói: "A única solução possível, quando se está suficientemente longe da realidade, é morrer, uma vez 
que todas as razões de se viver, que o homem dá a si mesmo, são ilusões" (MOUNIER, 1971, p. 337, tradução nossa). ${ }^{4}$

Em Hermilo, nem todos os personagens mais jovens sucumbem, mas não são necessariamente vencedores. Em João sem terra, após o resgate de Paula, encontrada ao amanhecer, nua, deitada ao lado de João, seu pai, Conrado ainda permanece na mata, junto com o pai, "gritando um pro outro". Ao retornar para casa "com o rosto rasgado por unhas, todo desfeito", anuncia a morte de João. Seu corpo encontra-se no fundo do rio, "com uma pedra amarrada no pescoço" (BORBA FILHO, 2007, p. 147). Sugere-se o suicídio do patriarca que, nesse momento, já perdera todo e qualquer vínculo com a realidade. Mas sua morte não pressupõe apaziguamento ou triunfo do filho sobre o irracionalismo do pai:

(E faz-se uma pausa dolorosa. Conrado caminha até Ana, agarra-a pelos ombros e os dois se olham, mais uma vez, com inquietação.)

Conrado - Paula...?

Ana - Lá dentro.

Conrado - Antes de ir pro fundo do rio... ele me disse...

Ana - Não quero saber!

Conrado - É filha dele?

Ana (Não pode mentir) - É...

(Afasta-se e vai para a janela. Os braços do rapaz caem ao longo do corpo. Paula aparece na porta e fica assim, sem tirar os olhos de cima dele. Depois vem caminhando devagar. Antes de chegar, porém Conrado se adianta e chama-a para si. O abraço não tem mais fim. O ruído dos machados cortando as árvores já está perto de casa) (BORBA FILHO, 2007a, p. 147-148).

\footnotetext{
${ }^{4}$ No original : "La seule solution possible, quand on est assez loin dans la réalité, est de mourir puisque toutes les raisons de vivre que se donne l'homme sont des illusions ».
} 
O final é ambíguo. Não se sabe se a revelação de João irá frear a atração que os jovens irmãos nutrem um pelo outro ou não. Simbolicamente, a sombra do pai não os abandona. Caso deem continuidade ao enlace amoroso, perpetuarão a sexualidade incestuosa e irracional de João; caso eles se separem, o veto paterno será mantido, preservando seu último pedaço de terra (o corpo de Paula) do "cultivo" de outro homem. E o ruído das árvores sendo cortadas, cada vez mais próximo da casa, tem a função de um vaticínio: seja de uma destruição ainda maior, seja do início de um novo ciclo.

Em A barca de ouro, praticamente todo o núcleo familiar deseja a mesma mulher: Dona. Sem muita explicação ao longo da peça, sabe-se que o filho Anselmo mata o antigo noivo de Dona, conhecido como Zé Pinga, após tomar-lhe a moça. O crime permanece sem esclarecimento e o corpo está desaparecido; em verdade, tragado pelas águas do mar. Dona não nasceu na ilha e é acolhida pela família de Anselmo, tornandose sua noiva e, em seguida, sua esposa. A irmã de Anselmo, Corina, alimenta uma paixão mórbida por Dona. Recusa-se a casar com qualquer homem da ilha para não sofrer o mesmo destino das outras mulheres, isto é, o de permanecer sozinha à espera do marido ou condenada à viuvez. O patriarca da família, apenas identificado como Pai, também cobiça Dona, de maneira explícita, e coloca-se como rival do próprio filho: "Tenho gosto de sangue na boca! [...] Eu preciso dessa mulher... Ela tem que ser minha. Não quero outro homem entre mim e ela" (BORBA FILHO, 2007b, p. 46). O Pai incita o filho a se deixar atrair pela Moça Loura da barca de ouro, além de denunciar o seu crime a polícia, para que ele possa tomar Dona à força, sem nenhum impedimento. Depois que Anselmo é levado pela barca de ouro (destino de todos os 
pescadores), o Pai diz: "Louvado seja Nosso Senhor Jesus Cristo!" (BORBA FILHO, 2007b, p. 94). Sem a proteção do marido, assediada tanto pela cunhada quanto (e, sobretudo) pelo sogro, Dona se suicida.

O mar é a grande força de atração dos homens e principal rival das mulheres. Seu poder simbólico sobre os personagens é mais intenso do que o da terra em João sem terra. Ele assemelha-se à onipresença do mar em Senhora dos afogados, de Nelson Rodrigues, que seduz e ameaça a família Drummond. Em ambas as peças, o mar exerce um poder de atração nos personagens, de conotação sexual, mas também carregado de morbidez. Em A barca de ouro, por exemplo, não há sentido na vida dos pescadores se eles não morrerem no mar. Eles não temem a morte, assim como não demonstram temor pelo mar, nem pela barca de ouro:

Anselmo - É o primeiro homem da família que morre em terra.

Pai - Longe do mar.

Anselmo - Não viu a barca de ouro.

Pai - Também ele já estava muito velho para andar pelo mar... Anselmo - Mesmo assim pedia todos os dias que a gente levasse ele para lá. Queria ver a barca de ouro.

Pai - Ela não aparece a quem não pode navegar com suas próprias forças.

Anselmo - Todos os homens daqui de casa têm morrido no mar.

Pai - Depois de verem a barca de ouro.

Anselmo - É o sinal.

Pai - Que um dia haverá de chegar pra gente também.

Anselmo - Haverá...

Pai - Deve ser horrível morrer em terra.

Anselmo - Que esse castigo nunca chegue pra mim.

Pai - Que Deus o livre. (BORBA FILHO, 2007b, p. 4o).

Em Borba Filho, a força do instinto, da sexualidade, é representada prioritariamente pelos pais - e, por extensão, pelos elementos da natureza, como terra e água - que buscam destruir os filhos para 
conquistar a terra ou a fêmea desejada, como ocorre em João sem terra e A barca de ouro. O Pai e João se equivalem enquanto forças repressoras, conduzidas por sua pulsão sexual. Todavia, o que os diferencia é a irracionalidade que acomete João.

Em Electra no circo, o tema da sexualidade se manifesta de modo pontual, sobretudo durante os delírios do Rapaz do Trapézio quando este enlouquece e é internado em um hospício, após o assassinato da Equitadora e do Domador. Em suas alucinações, a Moça do Arame o abandona para se casar com o Dono do Circo, pai de ambos. Em uma mesma cena, sugere-se, em suas fantasias, tanto o incesto entre irmãos quanto o incesto entre pai e filha. Ao final da peça, o Rapaz do Trapézio também se suicida como forma de libertação de si mesmo.

\section{Abstração}

Outro traço expressionista recorrente é a presença de personagens desprovidos de individualidade. Em algumas peças, os personagens não possuem nomes próprios, como se respondessem a um instinto ou função básicos, a uma força mais poderosa e essencial, que extravasa a racionalidade ou as normas sociais: isso ocorre em Electra no circo, em que os personagens não se nomeiam, apenas respondem a designação de suas funções no circo. Quando são interpelados por seus nomes próprios, reagem de modo intempestivo:

A Cantora - Não aguento mais. Fique aí sozinha com a sua loucura.

A Moça do Arame - Vá pra junto daquela que matou o meu pai.

A Cantora - Helena! 
A Moça do Arame - Não pronuncie o meu nome. Vá embora. Vá embora! (A Cantora sai). (BORBA FILHO, 2007a, p.40)

Em A barca de ouro, apenas os jovens possuem nomes próprios (Anselmo, Dona e Corina), enquanto que os demais são as figuras do Pai, do Tio e da Moça Loura, além dos diversos coros que compõem a peça: coro dos pescadores, coro das donzelas, coro das viúvas. Essa designação mista, separando personagens de figuras arquetípicas, demarca a divisão e o enfretamento entre o indivíduo e seu meio, entre os jovens e o domínio paterno.

Por intermédio desse recurso, pode-se perceber também ainda outra característica expressionista: a tendência para a abstração. $\mathrm{O}$ expressionismo apresenta uma visão essencial do homem. Retirando todos os aspectos localistas, ele tende para a abstração. Esse recurso, de certa forma, é atingido por Hermilo, principalmente em $A$ barca de ouro e em Electra no circo. Apesar de podermos identificar o ambiente que circunscreve e atua sobre os personagens ou figuras (em Electra no circo, Hermilo apenas os denomina de figuras) - o circo e o mundo da arte, a ilha de pescadores e a atração do mar, o engenho de fogo morto e a força da terra -, a cor local, as características da região e sua cultura, apresentase de modo difuso, permanecendo em segundo plano e prevalecendo certa abstração trágica das forças pulsionais que movem seus personagens/figuras. Esse aspecto apresenta uma contradição no projeto estético de Hermilo, visto que as riquezas da cultura nordestina permanecem mais como tema do que como forma, restando aos recursos expressivos importados do expressionismo a via de acesso à consecução de um drama moderno. 


\section{Atividade monológica e atividade coral}

Ainda outra característica da dramaturgia expressionista presente, dessa vez, apenas em Electra no circo é a presença de uma extensa e intensa atividade monológica. Esse procedimento é inaugurado com a peça $O$ caminho de Damasco, de August Strindberg, no qual os acontecimentos dramáticos são frutos da atividade psíquica do protagonista: "A sucessão fatual, o tempo e os lugares da representação ordenavam-se como projeções da vida interior em que a razão não se sobrepõe às emoções, às intuições e à experiência sensorial" (LIMA, 2002, p. 200). Nesse tipo de procedimento "a consequência da atividade do drama é de ordem interior" (LIMA, 2002, p. 201). Isento de causalidade, a trajetória do herói cria personagens, espaço, tempo e situações "adequados para expressar estados anímicos ou problemas existenciais imperativos" (LIMA, 2002, p. 200).

Em Electra no circo, a atividade monológica manifesta-se de diversas maneiras, refletindo essencialmente a vida interior da Moça do Arame e do Rapaz do Trapézio. Ambos são acometidos por vozes, sombras, fantasmas do passado, atuando frequentemente como duplos que acompanham suas falas e ações tal qual uma voz interior, evocações mnemônicas ou manifestações do inconsciente.

Na lista de figuras da peça, destaca-se uma "figura" que é nomeada apenas como "A Voz". Sua presença acústica atravessa o primeiro e segundo ato da peça. Ela ecoa o estado interior ou procura influenciar as atitudes da Moça do Arame e do Rapaz do Trapézio:

\footnotetext{
A Moça do Arame - Não acha que chegamos muito cedo? O Homem Lagarto (Faz um sinal negativo com a cabeça)
} 
A Moça do Arame - O Que eu não daria para estar hoje longe do circo...

O Homem Lagarto (Espanta-se como se a moça houvesse dito uma barbaridade e entra para trocar de roupa)

A Voz - Hoje, mais do que nunca, os meus pés estão pesados. Sinto-os como parte independente do corpo.

(Ouve-se a voz do Homem Lagarto trauteando uma canção qualquer)

A Voz - Os pés estão pesando como se fossem de chumbo. Que pressentimento! Eu não posso continuar a viver assim. É como se sentisse alguém ao meu lado... (Pausa) Os meus pés estão pesando... estão pesando... Como posso andar no arame? E logo hoje, que vai estrear o meu novo companheiro... (BORBA FILHO, 2007, p. 30).

Tanto a Moça do Arame quanto o Rapaz do Trapézio são assombrados por vozes acusmáticas, isto é, vozes sem uma origem física identificável, que refletem a cisão psíquica do sujeito. De acordo com a ensaísta Cláudia Maria de Vasconcelos (2017, p. 43), "O Doppelgänger é um dos modos de duplicação de personagem - a visão de si mesmo num outro -, e peça de ação multiplicativa. Há, contudo, outro modo duplicativo, em que o personagem não se multiplica, nem duas, nem mais vezes, mas se duplica por cisão". Em Electra no circo, há um jogo entre imagem e voz, "em que esta comparece separada de seu suposto emissor ou pensador" (VASCONCELOS, 2017, p. 43). Em verdade, há uma multiplicação de vozes e presenças que expõe a fragmentação do sujeito e que, seguindo sua veia expressionista, demonstra que os acontecimentos dramáticos decorrem da atividade psíquica dos protagonistas.

Algumas vezes, essas vozes interrompem a ação dramática como se fossem fragmentos da memória. São ao mesmo tempo sombra e voz: 
A Moça do Arame - Que é? Não posso falar?
O Homem Lagarto (Faz um gesto evasivo)

A Moça do Arame - Pois não me calo. Não me calo! Grito! (Afasta-se para um canto) Não quero esquecer meu pai.

(Apagam-se as luzes. Novamente a parede transparente. Silhuetas: o Dono do Circo sentado em uma cadeira de balanço, defronte de uma mesa. Entra a Sombra da Moça do Arame.)

Voz do Dono do Circo - Onde você estava, minha filha? Voz da Moça do Arame - Fui à padaria.

Voz do Dono do Circo - Por que não mandou seu irmãozinho?

Voz da Moça do Arame - Ele está dormindo.

Voz do Dono do Circo - Venha ler para mim, venha.

Voz da Moça do Arame - E mamãe?

Voz do Dono do Circo - Foi ao cinema. É sempre assim quando não tem espetáculo.

Voz da Moça do Arame - Cadê o livro?

Voz do Dono do Circo - Aí em cima da mesa.

(A Sombra da Moça do Arame pega o livro, senta-se e começa)

Voz da Moça do Arame - "Quando o Conde Florian sentiu os efeitos do veneno começou a gritar palavras horrorosas contra aquela mulher que ele tanto havia amado. Sentia que a morte se aproximava e..."

(A Voz vai se perdendo, as luzes vão acedendo, as Sombras desaparecem) (BORBA FILHO, 2007a, p. 30).

Outras vezes, ganham corpo e atuam no presente, assumindo a forma de um ente querido, um fantasma do passado:

A Moça do Arame - E você pensa que posso esquecer meu pai?

(Dentro de um foco luminoso, a um lado do palco, aparece o Dono do Circo).

A Cantora - Não se trata de esquecê-lo, mas de esquecer o que aconteceu.

O Dono do Circo (Voz ciciada) - Minha filha, minha filha, escute.

A Moça do Arame - Foi sua mãe quem deu esses conselhos? 
O Dono do Circo - Escutem-me... escutem-me...

A Cantora - Acredite que ela só quer o seu bem.

A Moça do Arame - Ela? Aquela assassina?

A Cantora - Não diga isso.

O Dono do Circo - Aquela assassina...

A Moça do Arame - Que não hesitou...

O Dono do Circo - ... em cometer um crime monstruoso.

A Moça do Arame - ... em cometer um crime monstruoso.

A Cantora - Cale-se!

O Dono do Circo - Eu fui assassinado.

A Moça do Arame - Eu preciso vingá-lo

(BORBA FILHO, 2007a, p. 38-39).

De maneira geral, atuam como espécie de duplos que são vistos ou ouvidos apenas pelo próprio protagonista e os leitores-espectadores, tendo como função na peça ecoar o estado interior dos personagens, seus desejos e temores; ou corroborar para a consecução de suas intenções ocultas e ideias obsessivas.

Dentre as três peças estudadas, do ponto de vista temático, Electra no circo é a peça que mais se aproxima das tragédias gregas, ao se apropriar do mito. Todavia do ponto de vista formal, dos procedimentos dramatúrgicos empregados, é a que apresenta maior arsenal de procedimentos da dramaturgia expressionista. Enquanto João sem terra e $A$ barca de ouro são obras que apresentam temas expressionistas, Electra no circo experimenta mais ostensivamente procedimentos típicos da poética expressionista.

Como em muitas peças expressionistas, em Electra no circo, a ênfase expressiva repousa na entonação e no gesto, explicitados minuciosamente nas rubricas. A pontuação do texto, profusa em reticências, sugere a contiguidade entre pensamento e fala. De modo menos enfático, em João sem terra e $A$ barca de ouro ainda se pode encontrar certa exploração no uso das reticências, nas descrições das rubricas e no uso de cenários simbólicos: uma casa envolvida pela mata 
ou pelo mar, apartando seus personagens do crivo da civilização e da racionalidade.

Todavia, em Electra no circo esses procedimentos são radicalizados, principalmente no último ato, quando toda a ação se passa na mente do Rapaz do Trapézio, na vida interior que se desintegra progressivamente até o seu suicídio. Hermilo descreve e explica, com precisão, a forma e o sentido do novo espaço cênico da peça:

\begin{abstract}
Abre-se o pano de boca. Dois palcos superpostos. Ambos estão com as cortinas cerradas. No de cima, que é alguma sala de sanatório, movimentam-se os personagens reais. No debaixo, uma rotunda escura que é o cérebro do Rapaz do Trapézio, tem lugar as cenas imaginadas pela sua loucura (BORBA FILHO, 2007a, p. 61).
\end{abstract}

Aqui, há uma imersão vertical na subjetividade. As cenas que se passam no palco inferior, o das alucinações, são tomadas por aparições, sombras e vozes acusmáticas. Por intermédio das didascálias, o dramaturgo sugere efeitos cênicos típicos da encenação expressionista:

\begin{abstract}
Abre-se a cortina inferior. Trevas. Silêncio. Um número 13 luminoso, muito grande aparece ao fundo. Desaparece. Torna a voltar. Está fixo por um instante. Some-se. Volta. Apaga-se. Escuridão. Em surdina, um toque de clarim. Prolongado. Vaise esgarçando. Fugiu. O número 13 vem e volta, rapidamente. Um fiapo de luz penetra nas trevas. A luz vai subindo em resistência. Não passa de penumbra, porém, durante quase todo o tempo (BORBA FILHO, 2007a, p. 62).
\end{abstract}

Uma última vertente que destacamos da veia expressionista desse conjunto de peças diz respeito à ostensiva atividade coral, presente, sobretudo, em Electra no circo e A barca de ouro. Intercalando coros recitados, cantados e, por vezes, dançados, essas peças reforçam a 
herança trágica que sustenta o projeto expressionista e que, por sua vez, inspira Hermilo.

\section{Desvio metateatral}

Para além do procedimento de teatro dentro do teatro, o advento da autoconsciência e reflexividade no interior da obra teatral são determinantes para o que se convencionou chamar de metateatro ou metadrama. É o dramaturgo e crítico teatral norte-americano Lionel Abel que expande o teatro dentro do teatro, forjando o termo metateatro, em 1963, cujos paradigmas são as peças $A$ vida é um sonho, de Calderón de la Barca; A Tempestade e, sobretudo, Hamlet, de William Shakespeare. Segundo a hipótese de Abel, o gênero metateatral surge em decorrência da impossibilidade de se escrever tragédias tais quais foram escritas na Antiguidade Clássica. Para ele, talvez baseado na unidade de ação aristotélica, a inatividade do personagem e seu caráter reflexivo imprimem-lhe um viés filosófico, que o afasta do gênero trágico: "Skakespeare dignifica a inatividade de Hamlet, fazendo-a filosófica" (ABEL, 1968, p. 68).

Sua observação quanto à forma reflexiva da obra shakespeariana não recai apenas no uso do artifício do teatro dentro do teatro. Ela se dá a partir de uma compreensão dos personagens como dramaturgos da própria ficção em que estão imersos. Ou seja, em vários momentos, alguns personagens agem como dramaturgos ou encenadores, conduzindo o comportamento ou atitude de outros personagens: "alguns são fundamentalmente dramaturgos ou pretensos dramaturgos, e os outros são fundamentalmente atores. Assim, Gertrudes e Ofélia, bem 
como Laertes, são atores; mas Hamlet, Claudio, Polônio e o Fantasma são dramaturgos" (ABEL, 1968, p. 74).

Para além do recurso do teatro dentro do teatro, o que caracteriza uma peça como metateatral é o fato dessas obras apresentarem "a vida como já teatralizada”. Seus personagens agem e têm consciência (ou concepção) da vida como sendo uma representação. Dessa forma, sua teatralidade torna-se um elemento consciente dentro da própria ficção.

Retomando o raciocínio de Abel, a poética metateatral parece ser um desvio do projeto de se escrever uma tragédia moderna, tributária da herança da Antiguidade clássica. Não sendo mais possível a tragédia, escrevem-se peças filosóficas, autorreflexivas, como são exemplos os autores Luigi Pirandello, Jean Genet e Samuel Beckett. Como desvio também se dá a ver a veia metateatral de Electra no circo. Os três atos que dividem a peça são respectivamente nomeados como: Antes do espetáculo, Durante o espetáculo, Depois do espetáculo. A peça se passa em um circo, ou seja, todos os personagens são artistas que aguardam a chegada do público e se preparam para o início do espetáculo. Se, nos dois primeiros atos, Hermilo disfarça a origem literária e mítica de seus personagens; no terceiro, estes surgem nos delírios do Rapaz do Trapézio trajando vestimentas gregas, assumindo a fábula que lhes deu origem: eles tornam-se então Agamêmnon, Clitemnestra, Egisto, Electra e Orestes.

Há ainda um Mestre-de-Cerimônias que aparece sempre no começo de cada ato. Ele anuncia o espetáculo O grande circo do mundo, explícita referência à peça $O$ grande teatro do mundo, de Calderón de la Barca, que também é um texto paradigmático das origens do gênero metateatral, além de ter sido traduzido pelo próprio Hermilo. Assim 
como em Seis personagens em busca de um autor, de Pirandello, Hermilo nos apresenta uma representação malograda, pois se na obra do autor italiano os personagens impedem o ensaio dos atores para poderem viver suas próprias vidas; em Electra no circo, segundo o Mestre-deCerimônias, o início do espetáculo é sempre retardado para que os artistas possam "viver a própria tragédia" diante do público:

\begin{abstract}
Mestre-de-Cerimônias - Respeitável público, não é culpa nossa se os artistas do nosso circo quiseram viver uma história própria antes do espetáculo. Quando eu aqui apareci pela primeira vez, anunciei que iriam ver os números sensacionais do Grande Circo do Mundo. Fiquei tão surpreso quanto a distinta plateia ao verificar que os artistas estavam mostrando um pedaço das suas vidas, um drama doméstico que nada tinha a ver com a sua condição de artistas. Procurei interrompê-los, mas nada consegui. Tentei fazê-los compreender que o público desejava ver as acrobacias no trapézio, o cachorro equilibrista, as anedotas pornográficas do palhaço. Eles não me ouviram. E sabe, respeitável público, o que me disseram? Pois bem: me disseram que já estavam cansados de sua condição de fantoches, que queriam viver a sua própria história. Que queriam viver, respeitável público! (BORBA FILHO, 2007a, p. 47)
\end{abstract}

A citação a Pirandello é clara. Hermilo escreve parafraseando o escritor siciliano e, por meio desse personagem-narrador, ele insere de maneira mais explícita a natureza autorreflexiva de sua obra. Aqui, vislumbra-se em Hermilo o homem de teatro, simultaneamente dramaturgo e teórico, mas, sobretudo, o aprendiz da cena. O metateatro no teatro moderno é um desvio do objetivo inicial de se escrever tragédias na modernidade. $\mathrm{O}$ expressionismo também não deixa de ser uma tentativa de atualização da herança trágica grega. Por todas essas trilhas, Hermilo, em um contínuo processo de autoaprendizagem, busca atingir o ideal de um teatro moderno no Nordeste do Brasil com suas tragédias regionalistas. 


\section{Referências}

ABEL, L. Metateatro: uma nova visão da forma dramática. Trad. Bárbara Heliodora. Rio de Janeiro: Zahar, 1968.

BORBA FILHO, H. O’Neill pelos universitários. Folha da Manhã. Recife, 11 ago. 1949 .

Hermilo Borba Filho: teatro selecionando, vol. 1. Org. Leda Alves e Luís Augusto Reis. Rio de Janeiro: Funarte, 2007 a.

. Hermilo Borba Filho: teatro selecionando, vol. 2. Org. Leda Alves e Luís Augusto Reis. Rio de Janeiro: Funarte, 2007b.

IVERNEL, P. L'abstraction et l'inflation tragiques dans le théâtre expressioniste allemand. In: BABLET, D.; JACQUOT, J. (Dir.). L'Expressionisme dans le théâtre européen. Paris: CNRS, 1971, p. 77-91.

LIMA, M. A. Dramaturgia expressionista. In: GUINSBURG, J. (Org.). O expressionismo. São Paulo: Perspectiva, 2002, p. 189-221.

MAGALDI, S. Panorama do teatro brasileiro. 5. ed. São Paulo: Global, 2001. MOURNIER, C. L'Expressionisme dans l'Oeuvre d'Eugene O’Neill. In: BABLET, D.; JACQUOT, J. (Dir.). L’Expressionisme dans le théâtre européen. Paris: CNRS, 1971, p. 329-340.

REIS, L. A. V. P. Fora de cena, no palco da modernidade: um estudo do pensamento teatral de Hermilo Borba Filho. Recife: Ed. Universitária da UFPE, 2009.

VASCONCELOS, C. M. Samuel Beckett e seus duplos: espelhos, abismos e outras vertigens literárias. São Paulo: Iluminuras, 2017.

Recebido em 06/10/2017.

Aprovado em 09/10/2017. 